JKIJMSS

@.JK Business School

Vol. 3 Issue No.1 \& 2 May 2020

Pages: 21-33

ISSN 2581-7337

https://www.jkbschool.org/research-journals/

\title{
Impact of Students Enrolled in Higher Education vis-à-vis Usage of e-PG Pathshala Resources: An Exploratory Study on Select Universities
}

\author{
Subhajit Panda \\ Chandigarh University, Mohali, Punjab (India) \\ 1Email: subhajit.e9641@cumail.in \\ Orcid id: http://orcid.org/0000-0002-1578-1159
}

\begin{abstract}
Purpose: The purpose of the study is to analyse the state-wise impact of uses of e-PG Pathshala by the students enrolled in higher education in India.The study examines the status of acceptance of e-PG Pathshala as an e-learning platform to among the students of higher education in different Indian states.

Methodology: The total visitors of e-PG Pathshala were collected manually from the official website of e-PG Pathshala, list of total number of Universities were collected from official website of UGC and the data of total enrolment of higher education was collected from AISHE final report 2018-19.
\end{abstract}

Analysis: Data analysis was done using spreadsheet software for enhanced visualization and to understand the arrangement and correlation between different variables of the data set.

Result: The study result shows that, maximum number of e-PG visitors, universities and enrolled students in higher education belongs to the state Uttar Pradesh. The statistical findings also indicate a significant and positive correlation between the variables.

Implications: The results of the study gave a clear picture of the acceptance of e-PG Pathshala among the students of different Indian states. And based on the value improvement and awareness programme can be done to those states where the number of e-PG visitors is very low.

Originality: No previous study could be identified dealing with the finding of the study.

KEYWORDS: e-PG Pathshala, OER, Impact of Universities, Impact of Enrolled Students

\section{INTRODUCTION :}

With the advent of the Computer and WWW, the word "electronics" now encompasses every part of our lives. In Education, e-learning through its application in ICT is evidence of its usage. Open Educational Resources (OER) are one of such movement which aims to provide the user with an easy defined platform where they can access their study material, course note, interactive videos for learning purpose and free of cost by reputed institutions and academicians. OER is consistent with UNESCO's constitutional commitment to "the free 
exchange of ideas and knowledge" (UNESCO, 2016). Among the few acknowledged OER, e-PG Pathshala has a wide impact in developing, promoting and advancing e-learning in India. It is one of the best platforms of e-learning for the students of post-graduate, research scholars and academicians. It covers a vast area of literature and in each subject field, there is a structured group of experts. They work as a team for the acceptance, rejection, improvement, update of e-contents on that particular subject area. This study examines how the total number of universities and the total number of students enrolled in higher education significantly affects the number of visitors to an OER Platform, here e-PG Pathshala.

\section{REVIEW OF LITERATURE:}

Research work in the field of e-learning and MOOCs are common in Library Science but proper attention in the field of Open Courseware (OCW) and its practical implementation like e-PG Pathshala in India has not been given so far. Some prominent research work which helps me to understand this study is mentioned below:

Maharaj (2018) in her paper "A Study on Role of e-PG Pathshala in the Development of e-Learning" covers the meaning of E-Learning, Objectives and advantages of e-PG Pathshala and its statistical usage of data in different fields. The study further covers the ratio of total number of visitors and registered visitors; state wise visitors in India with respect to total population of the state and total enrollment in higher education; and subject wise uploaded modules with respective visitors.

Jeyapragash, Rajkumar, and Muthuraj (2017) examined the e-content modules of e-PG Pathshala project in their study during May 2017 and further analyzed major subjects and sub categories of major subjects. The study identified that total 15416 modules has contributed by 6 major subjects with the Social Sciences as a major subject category (contributed 5917 Modules) whereas Medical and Health Sciences contributed only 483 modules. It was also suggested that the Medical and Health Science experts should come forward to contribute more e-content modules for the benefit of medical and health science students and research scholars.

Our present study is a further extension of the previous works, attempting to evaluate the state-wise correlation between the total number of students enrolled in higher education and the usage statistics of e-PG Pathshala.

\section{OBJECTIVES OF THE STUDY:}

1. To examine the state wise distribution of e-PG visitors in India;

2. To identify the effect of total number of university in the state-wise visitors count of e-PG Pathshala in India;

3. To investigate how the total number of student enrolled in higher education relates with the visitors 
count of a particular state in India;

4. To explore the demand of e-PG Pathshala as an Indian e-learning platform among the Pg-students in India;

5. To calculate the percentage of total enrolled student to total visitors oc e-PG Pathshala for a particular state in India;

6. To analyse statistically about the distribution and correlation between the variables, state-wise total visitors, total number of universities and total enrollment in higher education.

\section{SCOPE OF THE STUDY:}

The scope of this study is a limited but comprehensive research on the distribution of e-PG Visitors in different Indian states. The major implication of the study laid on the effect of total enrolled students and the total number of the university to the total visitors' count of e-PG Pathshala of a particular state. Average visitors per university, average enrolled student per university and percentage of the total enrolled student to total visitors gives the additional significance of the study. The study also tests the existence of a statistical test to examine the presence of any correlation between the three variables e.g. state-wise total visitors, the total number of universities, and total enrollment in higher education.

\section{RESEARCH METHODOLOGY:}

Data of the different areas of the study collected from different sources and the authentication of that particular source always given utmost attention. The total visitors of e-PG Pathshala was collected from the official website of e-PG Pathshala (e-PG Pathshala, n.d.-b) as of 23rd December 2019. List of Total number of Universities was collected from the official website of UGC (UGC, 2019) and the data of total enrollment of higher education was collected from AISHE final report 2018-2019 (MHRD, 2019). After collecting the raw data subsequent analysis of data was done using spreadsheet software for enhanced visualization. After extracting the raw data, thorough data mining is made to understand the arrangement and correlation between different variables of the dataset. In case of collection of data, full or partial extraction of data is done depending upon the field category. To examine how the distribution of visitors in each subject field relates to the number of uploaded modules for that subject in e-PG Pathshala, Pearson Correlation test was done using JASP (v. 0.12.2.0).

\section{DATA ANALYSIS:}

After the data collection is over, the raw data now analyzed by a simple quantitative method basically in form of average and percentage of the total, based on a set of relevant parameters suitable for interpreting the present study 


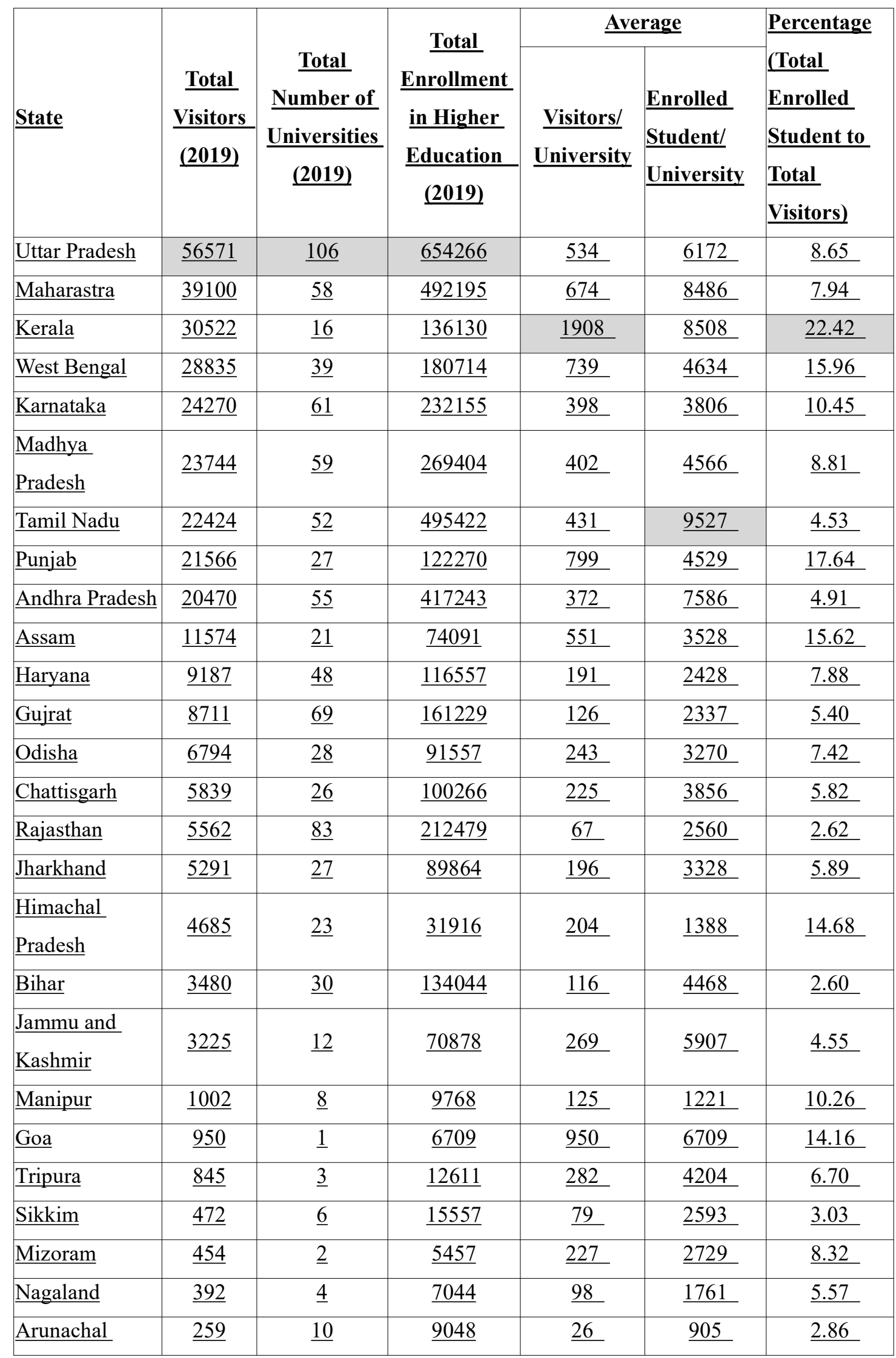




\begin{tabular}{|l|c|c|c|c|c|c|}
\hline$\underline{\text { Pradesh }}$ & & & & & & \\
\hline$\underline{\text { Meghalaya }}$ & $\underline{179}$ & $\underline{9}$ & $\underline{11008}$ & $\underline{20}$ & $\underline{1223}$ & $\underline{1.63}$ \\
\hline$\underline{\text { Andaman and }}$ & $\underline{12}$ & $\underline{0}$ & $\underline{1750}$ & $\underline{\text { NA }}$ & $\underline{\text { NA }}$ & $\underline{0.69}$ \\
\hline$\underline{\text { Nicobar }}$ & & & & & \\
\hline
\end{tabular}

Source: UGC Consolidated List of Universities:

https://www.ugc.ac.in/oldpdf/Consolidated\%20list\%20of\%20All\%20Universities.pdf

Source: AISHE Final Report 2018-19:

https://mhrd.gov.in/sites/upload_files/mhrd/files/statistics-new/AISHE\%20Final\%20Report\%202018-19.pdf

The value of all the upper parameter taken for the state Andhra Pradesh is the sum of the data of Andhra Pradesh and Telangana. e-PG Pathshala doesn't separate the value of total visitors for the two states because the state Telangana created later from Andhra Pradesh.

\section{Table 1. State Wise Total e-PG Visitors with respect to Total University \& Total Enrolled Student in Higher Education}

\section{STATE WISE DISTRIBUTION OF E-PG VISITORS:}

It is clear from the following figure 1 and table 1 that, the majority of e-PG visitors belongs to the state Uttar Pradesh [17\% (=56571)] followed by Maharastra (12\%) and Kerala \& West Bengal (9\% each). On the another side there are many states e.g. Manipur, Nagaland, Sikkim, Meghalaya etc which contribute very less amount of visitors $(\sim 0 \%)$ to the total.

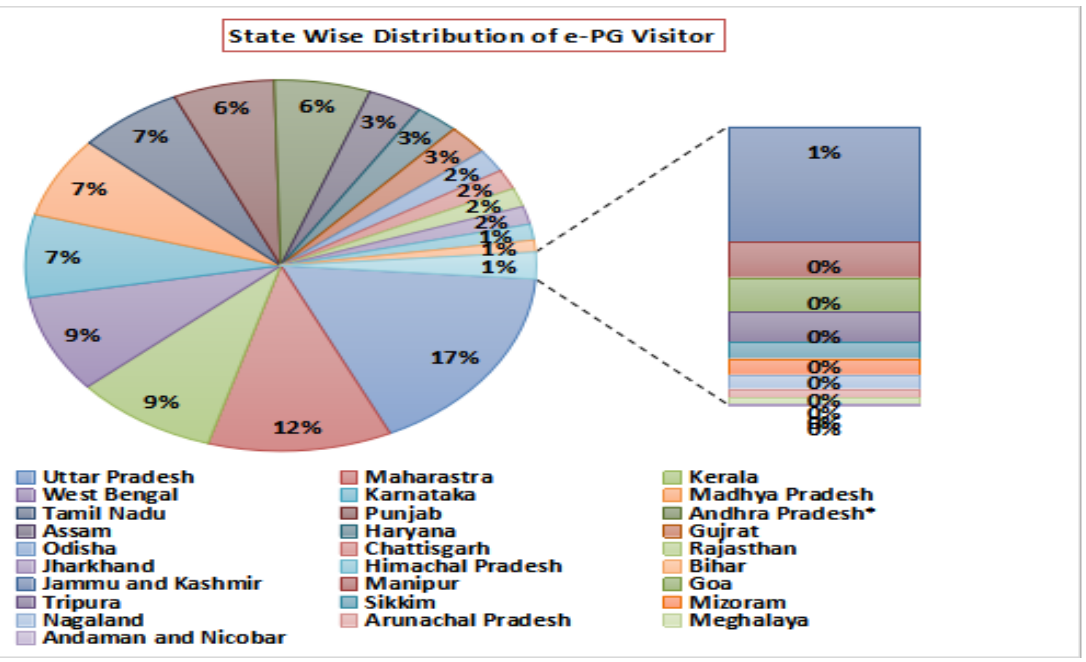

Figure 1. State Wise Distribution of e-PG Visitors

\section{STATE WISE DISTRIBUTION OF TOTAL NUMBER OF UNIVERSITIES:}

Following figure 2 and table 1 displayed that among the states of India, Uttar Pradesh occupied maximum number of universities [12\% (=106)] followed by Rajasthan (8\%) and Gujrat, Karnataka \& Madhya Pradesh (7\% each). It is also interesting to note that no university exist in Andaman and Nicobar island. 


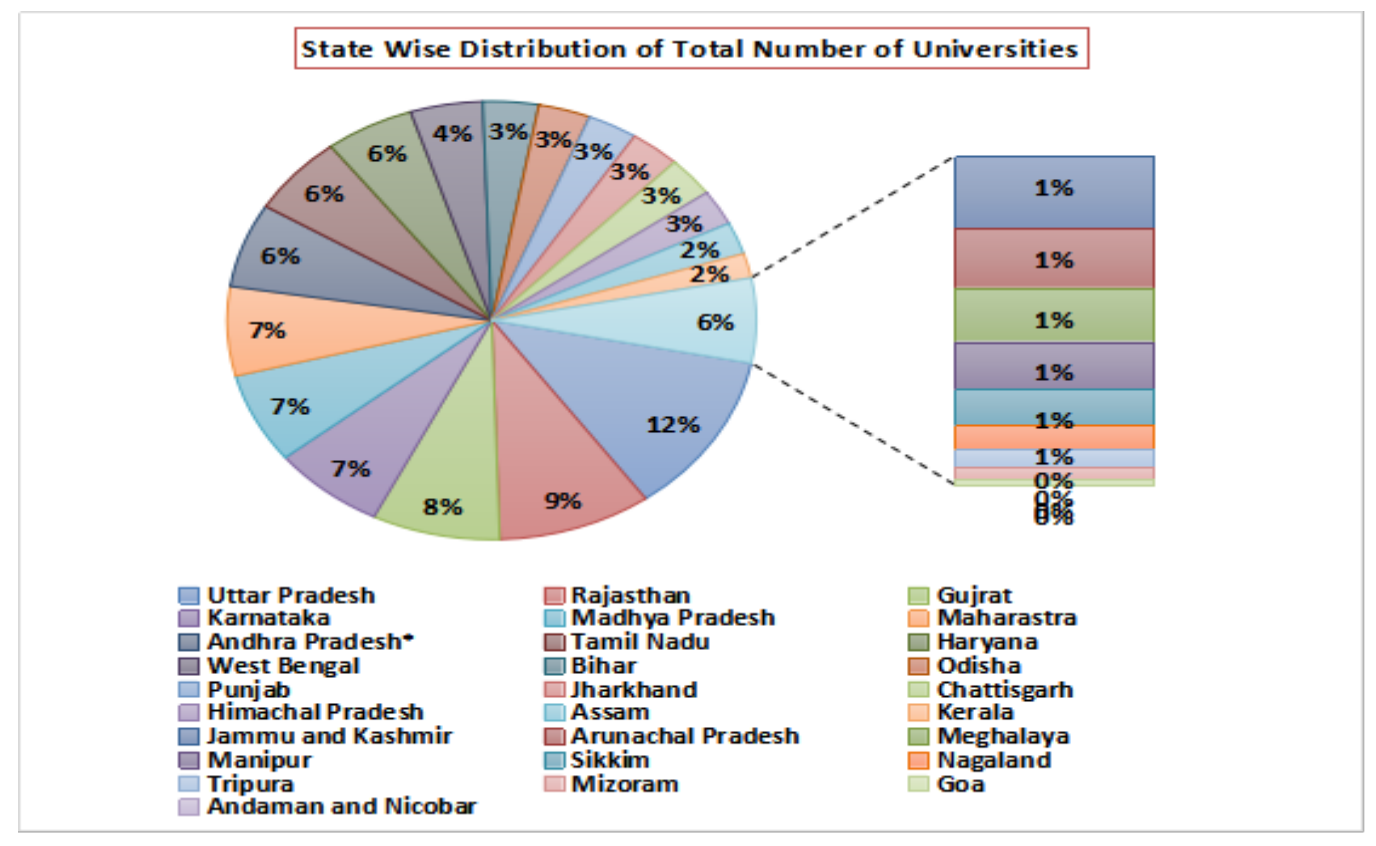

Figure 2. State Wise Distribution of Total Number of Universities

\section{STATE WISE DISTRIBUTION OF TOTAL ENROLLED STUDENTS IN HIGHER EDUCATION:}

Figure 3 shows that Uttar Pradesh with 16\% (=654266) enrolled students in higher education is the major contributor among all the Indian states. It is closely followed by Andhra Pradesh, Rjasthan (with $12 \%$ each) and Haryana (with 10\%).

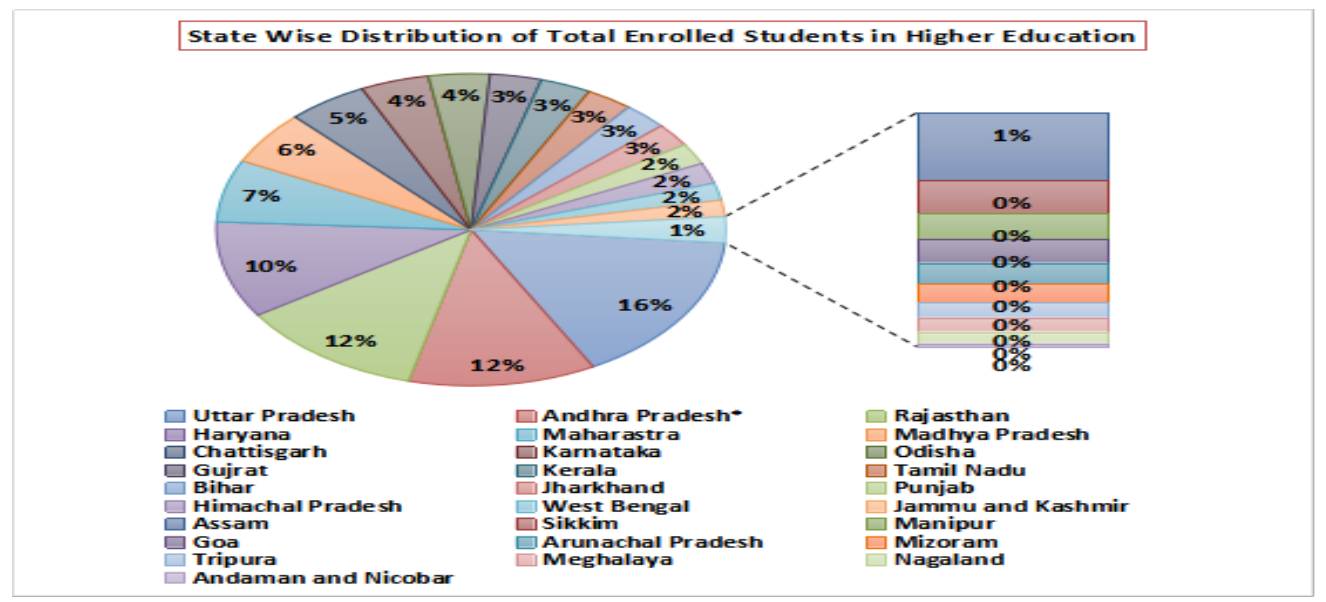

Figure 3. State Wise Distribution of Total Enrolled Student in Higher Education

\section{AVARAGE VISITORS AND ENROLLED STUDENTS PER UNIVERSITY:}

Figure 4 displays that the ratio of average visitors of e-PG Pathshala per university to average enrolled students in higher education (PG \& higher) is much low. From table 1 it can be identified that the state Kerala has the highest average value $(=1908)$ of visitors/university followed by Goa (=950), Punjab $(=799)$ and West Bengal 
(=739). Again, for the average value of enrolled students in higher education/university, Tamil Nadu obtained the maximum score (=9527) followed by Kerala (=8508), Maharastra (=8486) and Andhra Pradesh (=7586). It is interesting to note that due to the presence of a single university in Andaman and Nicobar island both the average evaluation is not applicable for it.

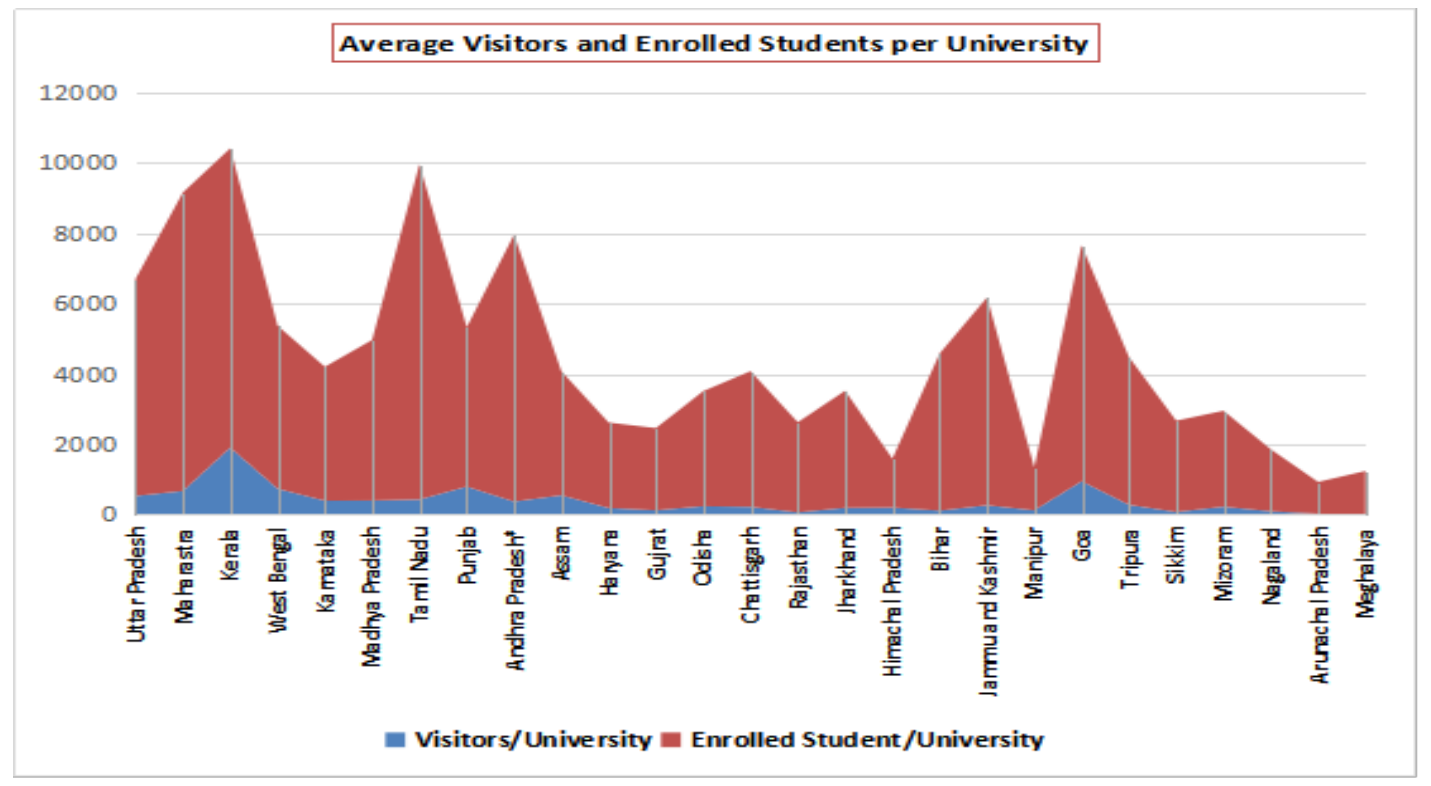

Figure 4. Average Visitors and Enrolled Students per University

\section{PERCENTAGE OF E-PG VISITORS TO TOTAL ENROLLMENT IN HIGHER EDUCATION:}

Figure 5 reveals that Kerala obtained the highest percentage (22.42\%) of e-visitors to total enrollment in higher education. It is followed by Punjab, West Bengal and Assam with a percentage of $17.64,15.96 \& 15.62$ respectively. Andaman and Nicobar island with a percentage of 0.69 placed the lowest position of the list.

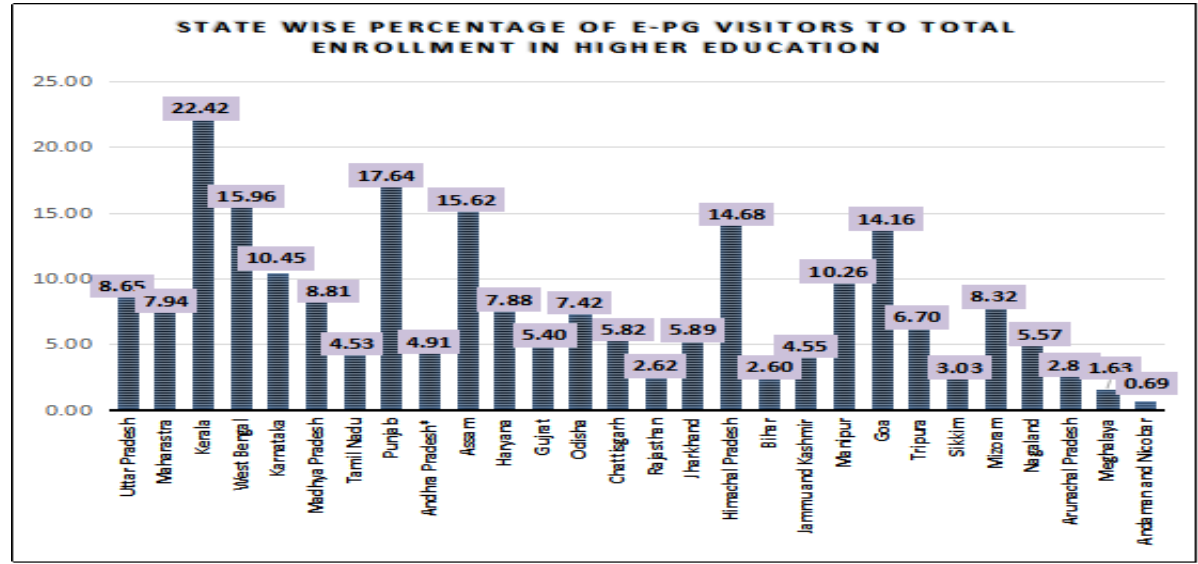

Figure 5. Percentage of e-PG Visitors to Total Enrollment in Higher Education 


\section{STATISTICAL ANALYSIS:}

\section{- PEARSON'S CORRELATION TEST:}

A correlation expresses the strength of linkage or co-occurrence between two variables. The most common measure of correlation in stats is the Pearson Product Moment Correlation (PPMC) which shows the linear relationship between two sets of data. The correlation coefficient between two continuous-level variables is called Pearson's $r$ or Pearson product-moment correlation coefficient which is represented typically as the letter $r$ and has a single value between -1 and +1 . This value measures the strength of the linkage (Laerd Statistics, 2020).

Significant correlations are marked with:

6. $\mathrm{p}<.05$ if the correlation is significant at alpha $=.05$ level.

7. $\mathrm{p}<.01$ if the correlation is significant at alpha $=.01$ level.

8. $\mathrm{p}<.001$ if the correlation is significant at alpha $=.001$ level.

\begin{tabular}{|l|c|c|c|c|c|}
\hline \multicolumn{5}{|c|}{ Table 2. Pearson's Correlations Matrix } \\
\hline & Pearson's r & p & $\begin{array}{c}\text { Lower 95\% } \\
\text { CI }\end{array}$ & $\begin{array}{c}\text { Upper 95\% } \\
\text { CI }\end{array}$ & VS-MPR † \\
\hline $\begin{array}{l}\text { Total Visitors - } \\
\text { Total Universities }\end{array}$ & $0.708^{* * *}$ & $2.500 \mathrm{e}-5$ & 0.455 & 0.855 & 1388.455 \\
\hline $\begin{array}{l}\text { Total Visitors - } \\
\text { Total Enrollment }\end{array}$ & $0.859^{* * *}$ & $4.904 \mathrm{e}-9$ & 0.715 & 0.933 & $3.921 \mathrm{e}+6$ \\
\hline $\begin{array}{l}\text { Total Universities - } \\
\text { Total Enrollment } \\
* \mathrm{p}<.05, * * \mathrm{p}<.01, * * * \mathrm{p}<.001\end{array}$ & $0.833^{* * *}$ & $3.680 \mathrm{e}-8$ & 0.668 & 0.920 & 583993.773 \\
\hline $\begin{array}{l}\dagger \text { Vovk-Sellke Maximum } p \text {-Ratio: Based on the } p \text {-value, the maximum possible odds in favor of } \mathrm{H}_{1} \\
\text { over Ho equals } 1 /(-\mathrm{e} p \log (p)) \text { for } p \leq .37 \text { (Sellke, Bayarri, \& Berger, 2001). }\end{array}$ \\
\hline
\end{tabular}

A strong correlation was observed between all the three pairs of variables; Total Visitors - Total Universities ( $\mathrm{r}_{\mathrm{p}}$ $=0.708, \mathrm{p}<.001)$, Total Visitors - Total Enrollment $\left(\mathrm{r}_{\mathrm{p}}=0.859, \mathrm{p}<.001\right)$, and Total Universities - Total Enrollment $\left(\mathrm{r}_{\mathrm{p}}=0.833, \mathrm{p}<.001\right)$. It is interesting to note that the nearer the value is to zero either positive or negative side), the weaker the relationship; and alternatively nearer the value is to +1 or -1 , the stronger the 
relationship in positive or negative side respectively. Table 2 represents the brief calculation the results of the correlations.

- CORRELATION PLOT:
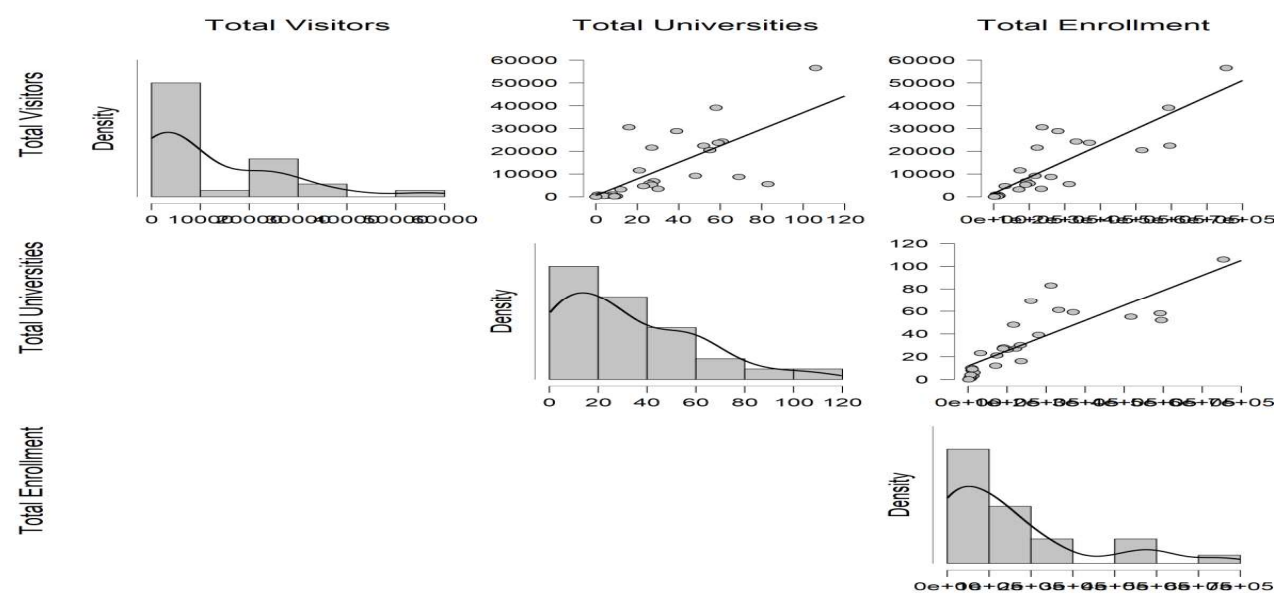

Figure 6. Pearson's Correlation Plot

.A Pearson correlation requires a linear relationship between each pair of variables. This hypothesis is violated if there is curvature among the scatter plot points within any pair of variables. Figure 6 above represents the scatterplot and the histogram of the correlation. It also indicates that there exists a linear correlation between the three pairs of variables (i.e. Total Visitors - Total Universities, Total Visitors - Total Enrollment, and Total Universities - Total Enrollment). The sharpness of the plot indicates the strength of the relation. A strong correlation displays by the sharp correlation plot of the rest two pairs of variables. The slope of the correlation plot determined the nature of the correlation (i.e. whether positive or negative). And in this case the slope indicates a strong correlation between all the three pairs of variables.

\section{FINDINGS \& DISCUSSION:}

The present study based on the findings of the correlation between total visitors of e-PG Pathshala with the total universities and total enrolled Pg-students in the different Indian States. Some key points which evolved after the core analysis of the study are listed below:

1. The majority of e-PG visitors belong to the state Uttar Pradesh followed by Maharashtra, Kerala and 
West Bengal.

2. Uttar Pradesh occupied the maximum number of universities followed by Rajasthan, Gujrat, Karnataka and Madhya Pradesh.

3. There is no university on the Island of Andaman and Nicobar.

4. Uttar Pradesh is the major contributor of students enrolled in higher education followed by Andhra Pradesh, Rjasthan and Haryana.

5. Kerala has the highest average value of e-PG visitors per University count followed by Goa, Punjab and West Bengal.

6. The average value of enrolled students in higher education/university, Tamil Nadu obtained the maximum score followed by Kerala, Maharashtra and Andhra Pradesh.

7. It is interesting to note that both the above mentioned average evaluations are not applicable due to the presence of a single university in Andaman and Nicobar island.

8. Kerala received the highest percentage of e-PG visitors to total higher education enrollment followed by Punjab, West Bengal and Assam, while Andaman and Nicobar Island were the lowest in the list.

9. Pearson's Correlation Test observed a strong correlation between all the three pairs of variables, namely, Total Visitors - Total Universities, Total Visitors - Total, and Total Universities - Total Enrollment.

10. This correlation test indicated that the existence of a greater number of university and enrolled students in higher education has a significant and positive impact upon the total visitors of e-PG Pathshala.

\section{FUTURE SCOPE:}

As discussed in the "Scope of the Study", the current research is comprehensive but limited on analyzing the impact of number of universities and number of enrolled students in higher education to the distribution of e-PG Visitors in different Indian states. Thus there is a lot of scope for new additions in that area. Global acceptance of Indian e-learning platforms can be a new area of research by analyzing the rate of foreign visitors in e-PG Pathshala. Again distribution of e-PG visitors in different subject areas and it's relation with the uploaded module and papers of that particular subject may also be considered for further research. Comparative study between different OCW platforms in India also the status of the same considering the popular OCW platforms of developed countries, the contribution of e-PG Pathshala in Indian digital literacy and it's use in SWAYAM platform also proved itself a unique and valid research problem.

\section{CONCLUSION:}

In the forum on the Impact of Open Courseware for Higher Education in Developing Countries, UNESCO first introduced the term OER in 2002. The first World Open Educational Resources Congress (UNESCO, n.d.), 
which was held in Paris, June 2012 and the second World OER Congress closed as experts and national delegates from 111 countries adopted by acclamation the 2017 Ljubljana OER Action Plan (UNESCO, 2017). Based on different working criteria OER can be broadly classified into OpenCourseWare (OCW) and Massive Open Online Courses(MOOCs). e-PG Pathshala is considered as an OpenCourseWare designed for the students of higher education e.g. Post Graduate, M.Phil., Ph.D., PG. Diploma etc. The universe of e-PG visitors is the students of higher education. Again, the number of students in higher education also depends on the presence of Universities of a State. Overall the assumption of the present study is significant that some correlation should present among them. The statistical findings of the study (after doing Pearson's correlation test) indicated that the existence of a larger number of university and enrolled students in higher education has a significant and positive impact upon the total visitors of e-PG Pathshala. 


\section{REFERENCE:}

e-PG Pathshala. (n.d.-a). About e-PG Pathshala. Retrieved December 21, 2019, from epgp.inflibnet.ac.in website: https://epgp.inflibnet.ac.in/\#

e-PG Pathshala. (n.d.-b). e-PG Stats. Retrieved December 23, 2019, from e-PG Pathshala website: https://epgp.inflibnet.ac.in/stats/home.php

JASP Team (2020). JASP (Version 0.12.2.0) [Computer Software]

Jeyapragash, B., Rajkumar, T., \& Muthuraj, A. (2017). An Analysis of e-content modules: with special reference to e-PG Pathshala. Indian Academic Library Association Journal, 5(2), 1-6. Retrieved January 10, 2020 ,

from https://www.researchgate.net/publication/323848347_An_Analysis_of_e-content_modules_with_special_refer ence to e-PG Pathshala

Laerd Statistics (2020). Pearson's product moment correlation. Statistical tutorials and software guides. $\begin{array}{lllll}\text { Retrieved } & \text { January } & 8, & 2020, & \text { from }\end{array}$ https://statistics.laerd.com/statistical-guides/pearson-correlation-coefficient-statistical-guide.php

Maharaj, N. G. (2018). A study on Role of e-PG Pathshala in the Development of e-learning. Knowledge Librarian, 5(1), 104-113. Retrieved January 10, 2020, from http://www.klibjlis.com/5.1.10.pdf

MHRD. (2019). All India Survey on Higher Education (2018-2019). Retrieved December 25, 2019, from https://mhrd.gov.in/sites/upload files/mhrd/files/statistics-new/AISHE\%20Final\%20Report\%202018-19.pdf

Sellke, T., Bayarri, M. J., \& Berger, J. O. (2001). Calibration of $\rho$ Values for Testing Precise Null Hypotheses. The American Statistician, 55(1), 62-71. https://doi.org/10.1198/000313001300339950

UGC. (2019, July 5). Total No. of Universities in the Country as on 05.07.2019. Retrieved January 3, 2020, from https://www.ugc.ac.in/oldpdf/Consolidated $\% 20$ list $\% 20$ of $\% 20$ All $\% 20$ Universities.pdf

UNESCO. (2016). Basic Texts. Retrieved January 1, 2020, from http://unesdoc.unesco.org/images/0024/002439/243996e.pdf 
UNESCO. (2017, September 18). WOERC Action Plan and Ministerial Statement - 2nd World OER Congress. Retrieved January 14, 2020, from https://www.oercongress.org/woerc-actionplan

UNESCO. (n.d.). World Open Educational Resources Congress | United Nations Educational, Scientific and Cultural Organization. $\quad$ Retrieved December 24, 2019, from https://webarchive.unesco.org/20160807000909/www.unesco.org/new/en/communication-and-information/eve nts/calendar-of-events/events-websites/world-open-educational-resources-congress/ 